\title{
Planning in uncharted waters: spatial transformations, planning transitions and role-reflexive planning
}

\section{Planung in unbekannten Gewässern: Räumliche Transformationen, Planungswandel und rollenreflexive Planung}

https://doi.org/10.2478/rara-2019-0012

Eingegangen: 14. April 2018; Angenommen: 29. Januar 2019

\begin{abstract}
For planners, processes of complex spatial transformations today are comparable to uncharted land and an uncertain voyage. Many possible role images overlap and contrast to traditional and established ways of thinking and acting. The focus here is on navigating instead of controlling, about supporting instead of enforcing. Planning lacks tools to think and act when facing uncertainty. This paper proposes role-reflexive planning as an educational and experimental approach to thinking through different potentialities. It offers groundwork from the boundary between planning and transition studies, using role-based ideas as a bridge. It offers an overview about different roles that are relevant to working towards transformations as spatial planners. It develops an account of role-reflexive planning that connects between contexts, actions and back to individual modes of behaviour in planning processes. As a basis, this paper condenses experiences of a role-playing pilot workshop and discussions about potential elements of a transition towards 'post-growth planning'. It outlines how role-playing challenges the individual roles of actors beyond the game situations themselves. Conceptual ideas foster a renewed role-based debate on thinking and acting in the face of uncertainty and ways to navigate through the stormy waters of transformation.
\end{abstract}

Keywords: Role of planners; role reflection; role-based approach

Zusammenfassung: Prozesse komplexer räumlicher Transformationen sind für Planer vergleichbar mit einem unerforschten Land oder einer ungewissen Reise. Viele mögliche Rollenverständnisse überlagern sich und stehen traditionellen und etablierten Denk- und Handlungsweisen gegenüber. Dabei geht es um Navigieren statt Kontrollieren, um Unterstützen statt Durchsetzen. In der Planung fehlen hingegen geeignete Werkzeuge, um bei Unsicherheit zu denken und zu handeln. Dieser Beitrag arbeitet rollenreflexive Planung als pädagogischen und experimentellen Ansatz heraus. Er bietet Grundlagen an der Schnittstelle von räumlicher Planung zur Transitionsforschung unter Verwendung rollenbasierter Ideen als Brücke. Er enthält einen Überblick über unterschiedliche Rollenverständnisse, die für Planung für und mit Transformationen für Planer relevant sind. Er entwickelt eine rollenreflexive Planung, die zwischen Kontext und Handlungen vermittelt sowie mit individuellem Verhalten in Planungsprozessen verbindet. Als Grundlage arbeitet der Beitrag Erfahrungen aus einem Rollenspiel in einem Pilotworkshop zur Transition zu einer Postwachstumsplanung auf. Er umreißt, wie Rollenspiele die eigenen Rollen von Akteuren über die individuelle

*Corresponding author: Dr. Christian Lamker, Technische Universität Dortmund, Fachgebiet Raumordnung und Planungstheorie, August-Schmidt-Straße 6, 44227 Dortmund, Deutschland, E-mail: christian.lamker@tu-dortmund.de 
Spielsituation hinaus herausfordern. Konzeptionelle Ideen fördern eine erneuerte rollenbasierte Debatte über Denken und Handeln unter Unsicherheit und Wege, durch stürmische Gewässer von Transformationen zu navigieren.

Schlüsselwörter: Rolle von Planern; Rollenreflexion; rollenbasierter Ansatz

\section{Planning in uncharted waters}

Planning has always been a process associated with uncertainties and different, multiple and overlapping ways of dealing with these uncertainties (Rittel 1972: 392 ff.; Christensen 1985: 63 ff.; Abbott 2005: 237 f.; Wiechmann/Hutter 2008: 103 f.; Ibert 2009: 90; Lamker 2016: 50 ff.; Rauws 2017: 32 f.). Current forces of global social and spatial transformations seem to accelerate the scope and dynamics of uncertainties. They challenge existing modes of thinking and acting by planners across spatial scales (Barnett/Parnell 2016; Loorbach/Wittmayer/Shiroyama et al. 2016; de Leo/Forester 2017; de Roo 2018). For some, this resembles an image of 'uncharted waters' that calls for creative experimentation, for new inclusive democratic approaches and for thinking through potentialities (Hillier 2010: 472 f.; Rauws 2017: 32 f.). However, there is a lack of adequate means of overcoming existing differences in society and experimenting with truly alternative ways of thinking. This article ponders on a reflexive and rolebased approach to assembling conceptual ideas for joint creativity and learning in complex environments. Starting from educational tools used to play with different perspectives and options for action, it lays the groundwork for refining planning tools to provide understanding of and motivation in ongoing processes of transformation.

Transformation and planning are increasingly connected to issues of governing processes of transformation, transformative experimentation and learning, and the changing roles of planners under fluidity and uncertainty (Lamker 2016; Loorbach/Wittmayer/ Shiroyama et al. 2016; Loepfe/Eisinger 2017; de Roo 2018; Knieling/Klindworth 2018). Planning for societal and spatial transformations includes the active creation and design of spaces for thinking and acting, co-production and adaptation and inclusive processes (Barnett/Parnell 2016; Friend/Anwar/Dixit et al. 2016; Rauws 2017). At the same time, it also involves concentrating on new ways of economic thinking in planning, about environments and qualities of life and about changing and transforming built-up areas. Above all, the focus shifts towards deeper underlying forces that drive spatial developments and manifold plannings (Ibert 2009: 91 ff.; Lamker 2016: $92 \mathrm{ff}$.). Social problems are too large to be completely understood prior to action, so concentrating on 'small wins' with a focus on inputs instead of outcomes is more promising, aiming "to incorporate a more substantial portion of psychology, specifically, its understanding of processes of appraisal, social construction of reality, problem finding, and definition of the situation" (Weick 1984: 40).

Transition research provides an elaborated framework to understand process dynamics and system changes (Geels/Schot 2007; Hutter/Egermann 2014). It allows a focus on paths of change within the domain and system of planning by providing a lens to analyse changing system conditions in distinct phases. Transformation is more closely connected to comprehensive spatial or social changes and is used here to describe wider processes of change (Friend/ Anwar/Dixit et al. 2016: 71; Hölscher/Wittmayer/Loorbach 2018: 2). Transformation and transition overlap in their meaning and tend to converge within the academic discourse (Hölscher/Wittmayer/Loorbach 2018: 2). They require a number of roles as temporary stabilisations that overlap, complement - and sometimes even contradict each other (Hutter/Egermann 2014: 9; Wittmayer/ Avelino/van Steenbergen et al. 2017: 53). The term role is not unique here. Conceptualising planning as a system of roles provides beneficial ideas for planning research and planning practice (Lamker 2016: 92 ff.), for understanding transition dynamics and emerging new niche and civil society actors (Hutter/Egermann 2014: 9), for creative work with ideas (Innes/Booher 1999: $11 \mathrm{ff}$. ), and also for teaching planning theory (Olesen 2018: 308 ff.). Most role-based studies converge in the importance they attribute to planning actions - they capture and analyse the actions in specific situations or daily practices (Lamker 2016: 37; Bisschops/Beunen 2018: 1 ff.). Rolebased approaches encompass abstractions from actions and their observable results (e.g. strategies, plans and other documents) and focus on the micro-level of individual actions, and ultimately individual planners (cf. Wittmayer/Avelino/van Steenbergen et al. 2017: 49 ff.). At the same time, most of them put great emphasis on a deep theoretical grounding, show an intense connection to planning research and theory, and encompass specific planning theories (Lamker 2016: $113 \mathrm{ff}$.; Olesen 2018: $310 \mathrm{f}$.). The concept of roles might be of specific help 
when developing deeper accounts of potentialities and possible changes. Roles have provided quick and easy to understand summaries of planning practices and can, on the other hand, be a bridge for thinking about different modes of behaviour with planning practitioners.

This paper takes a perspective between planning theory, organisation theory, sociological approaches and transition studies. It proposes using role-based playing to think 'out of the box' and become a creative force for manifold diverse actors working on spatial developments. This approach will be termed role-reflexive planning. Section 2 outlines basic thoughts for perceiving planning as a system of roles in transition. It connects existing role-based studies to the field of transition studies and multiple or fluid roles of planners. Section 3 adds thoughts from systems theory and organisation theory to conceptualise role-reflexive planning as an educational and experimental tool. A pilot experiment is used in Section 4 to explore the potential of fostering alternative thinking by focusing on a diverse set of roles that could be enacted in real-life environments. The experiences gained serve as groundwork to think through further practice-oriented potentialities of role-reflexivity. Section 5 takes a step further to propose possible efforts to use role-reflexive planning ideas with regard to processes of spatial transformation.

\section{Planning as a system of roles in transition}

Early role-based studies have focused on the daily practices of planners between technical, political and communicative tasks (examples are Rabinovitz 1969; Healey/Underwood 1978). More recent role-based approaches connect micro- and macro-levels of planning and look at actions as well as at organisations, institutions and rules in use (Howe/Langdon 2002: 213; Lamker 2016: 37). Other studies connect roles to individual planners and either their self-perspective or the outside perspective on their work (Steele 2009; Fox-Rogers/ Murphy 2016). Some further studies have embarked on conceptualising planning as an activity involving different roles at one time and over time (Ibert 2009; Lamker 2016), with the aim of loosening the connection between persons or formal positions and roles. The focus hereby shifts towards dynamic processes of enacting different roles by planners. It also entails the possibility for individual planners to move between different roles over time.
Transition research distinguishes between transition roles and roles in transition (Wittmayer/Avelino/van Steenbergen et al. 2017: 53). The former focuses on roles used to work for or against transitions. The latter refers to broader changes in roles themselves and in role constellations. In short, it is about existing planning of changing spaces or, more broadly, about including the changes in planning itself. Thinking through roles in transition includes analysing motivating forces behind changes and looking for new tools to think about possibilities to be an active part of these changes. Transitions in planning therefore mean adjusting or supplementing existing roles and rethinking relations between them, their interplay and underlying drivers and forces. In transition research, roles can be recognisable activities connected to social positions and interrelations, a resource perspective focusing on roles as socially produced and reproduced cultural objects or boundary objects with roles as temporary stable objects for analysis or action (Wittmayer/Avelino/van Steenbergen et al. 2017: 49 f.). The perspective focuses on single roles or on role constellations in transition or on roles as governance interventions (Wittmayer/Avelino/van Steenbergen et al. 2017: $50 \mathrm{ff}$.). This broad use and perspective targets the challenge of capturing complex real-life processes in their messiness. It highlights the importance of continuous reflexivity throughout the process (Scholl/Kemp 2016: $92 \mathrm{ff}$;; Wittmayer/ Hölscher 2016: 19 f.; Bisschops/Beunen 2018: 13 f.). The process of governing transitions then becomes "a continuous searching, learning and experimenting process through which roles are (re-)negotiated over a period of time and in which actors use roles to reach certain ends" (Wittmayer/Avelino/van Steenbergen et al. 2017: 53). Likewise, transitions are non-linear processes of searching and learning encompassing "a diversity of actors from different societal spheres (government, markets, civil society), who jointly learn about existing challenges and their root causes, explore social, technical and institutional innovations and change their behaviours" (Levin-Keitel/Mölders/Othengrafen et al. 2018: 3). Transition studies draw attention to processes that are rich in actors and roles, in which learning is fostered and in which actors ultimately change their own views and behaviours. Being aware of roles increases the capacity to act in time and over time.

Planning-related transition research has only recently begun to incorporate the idea of conceptualising planning practice and planning processes from a rolebased perspective (Egermann/Hutter 2014; Wittmayer/ Avelino/van Steenbergen et al. 2017; Kampelmann/ 
Kaethler/Hill 2018). This perspective searches for middle ground between individual and societal levels and conceptualises roles, among other uses, as partly open conceptions that leave space for alternative meanings and improvisations (Wittmayer/Avelino/van Steenbergen et al. 2017: 50). Transition research focuses on planning as activity and process. It is not bound to a public administration department or a private consultancy. Citizens become co-creators of urban spaces, but more importantly, impact on planning institutions, roles of professional planners and their own roles (Bisschops/ Beunen 2018: 13 f.). In this light, responsibility for thinking about changing roles has to be attributed to everyone involved in spatial transformations. This includes planners in public administrations, but also many more actors and their interplay. In the same vein, governance of transition in living labs is recognised as going beyond one-directional changes towards perceiving a reconfiguration and new design of capacities and capabilities (Bulkeley/Coenen/Frantzeskaki et al. 2016: 16). Long-term and comprehensive transformation can thus result from many modified actions by many different actors (Geels/Schot 2007: 406 f.).

A major future-oriented application of roles involves role-plays, simulation games and serious games. These have long used the power that lies in role-based thinking for playful accounts of testing prototypes, developing ideas or engaging in participatory processes (Poplin 2012; Rumore 2015; Gugerell/Zuidema 2017). Role-play simulations "can provide for experiential and immersive learning; create a safe space for experimentation and creative problem solving; foster perspective taking and empathy; and engage people in interactive learning and dialogue" (Rumore 2015: 19). This emphasis on social communication, interaction and learning resembles much of what is put forward by planning-related transition research. In particular, aspects of empathy, community and joint learning are prominent in recent studies that focus on system issues, interconnectedness and processes of change (Hölscher/Wittmayer/Loorbach 2018: 2; Kampelmann/Kaethler/Hill 2018: 60). However, little use has been made of this research direction to date.

Many applications in planning practice make clear delimitations between different roles, prescribe fixed and unchangeable roles to each actor and sometimes even include the role of a 'planner' (Scholles 2008: 394 ff.; Lamker 2016: 95 f.). Taking this approach allows the identification of common ground between roles, but fails to find common roles in which different actors can act. If roles are supposed to be tools for mutual understanding - as in many playful or game-based applications or when used for communicative planning efforts -, two actors can never really meet in joint ways of thinking. They can only find some compromise between their individual interests. Such a use of roles shows an overtly strong connection between the position of a person, his or her interests and his or her behavioural patterns. For example, private developers have an interest in maximizing profit and ignore social aspects, marginalised groups and wider community benefits. This approach remains important, but recent calls for co-creation, living labs and experimental approaches in planning require research to go further (Bulkeley/Coenen/Frantzeskaki et al. 2016: 16; WBGU 2016: 146 f.; Levin-Keitel/Mölders/Othengrafen et al. 2018: 3 ff.). System-based studies, including transition studies, search for roles in transition and processes demonstrating how tied connections between positions and persons and fixed role behaviours change. Roles hold the potential to become tools of engagement with multiple ways of planning prior to changing institutional or legislative environments. The systems perspective here focuses on small and immediate actions and simultaneously integrates their potential to yield largescale benefits and even system transformations.

\section{Role-reflexive planning}

With regard to planning, reflecting and being reflective are usually connected to a triangle between planners, context conditions (including external actors and the public) and planning actions. Planners reflect upon the situations, conditions and environments under which they act and plan. This holds true for pragmatist accounts of reflective practitioners and experimenting practices of planning (Schön 1983; de Leo/Forester 2017: 203), but also for sociological perspectives on reflexivity in planning (Howe/Langdon 2002: $212 \mathrm{f}$.) and for theoretical elaborations and studies focusing on reflexivity and agency (Emirbayer/Mische 1998; Lissandrello/Grin 2011; Hölscher/Wittmayer/Loorbach 2018). To use Schön and Rein's (1994: 37) proposition: "human beings can reflect and learn about the game of policy making even as they play it, and [...] are capable of reflecting in action on the frame conflicts that underlie controversies and account for their intractability". The object of reflection are the actions taken given the circumstances and means available, e.g. "actors may switch between (and reflexively transform) their orientations toward action, thereby changing their degrees of flexible, inventive, and critical response toward structuring contexts" (Emirbayer/ Mische 1998: 1012). This indicates a link between 
reflexivity about practical actions and a potential reflexive transformation of the actors themselves. Planning has a strong need to work with interactive practices across different forms of knowledge, divergent practices and worldviews and typologies of actors (Howe/Langdon 2002: 221 f.; Lissandrello/Grin 2011; Leo/Forester 2017: $214 \mathrm{f}$.). However, reflection mostly refers to the frame of action and the action itself, experimenting to actions implemented and observed changes.

Being reflective might also go further, not only giving actors a clear perspective about a given situation, but also changing their own mind-sets and ultimately enacted roles. The proposal here is the need to test potentials for including one's own role interpretations in reflexivity, and to coin this role-based reflection or, more process-focused, role-reflexive planning (cf. Lamker 2016: $324 \mathrm{f}$.). It is a means to continuously challenge anyone doing planning on the fly and thereby supporting immediate adjustments in a desired direction. It tends to ponder questions of "multiple imaginings of what might be possible" (Kaplan/Orlikowski 2013: 966). It is necessary to situate roles in time and to gain links between past, present and possible futures (cf. Kaplan/ Orlikowski 2013: 990). Important foundations for thinking through social systems - one of which is planning - by using the concept of roles is provided by the work of Niklas Luhmann (especially Luhmann 1983, 1987, 1997). He describes society as a hyper-complex system that produces multiple and differentiated self-descriptions. A hyper-complex system is produced by systems that try to capture their own complexity (Luhmann 1987: 637). Such a system enters a never-ending process of producing self-descriptions and including the reactions and effects of these: the system plans itself and its effects. However, it only produces a different picture of itself and does not simplify the actual system (Luhmann 1987: 45 ff.). Instead of reducing complexity, Luhmann talks about 'organised complexity' (Luhmann 1987: $46 \mathrm{ff}$.; Luhmann 1997: 22 f.). Possible behavioural patterns of actors in any social process - including planning - can be held together within one role that acts as a motivating force to include persons with their characteristics and self-conceptions (Luhmann 1983: 47 f.; Luhmann 1987: $430 \mathrm{f}$.). From this perspective, roles are elements that include a certain self-description of planners that is confined enough to be separated from others, but open enough to be used by different persons in different environments. Furthermore, working with different roles requires a degree of autonomy of process and visible selectivity (Luhmann 1983: 49). Hence, developing options for comparison needs inclusive processes, open communication, a strong process to connect them, and transparent - and therefore contestable - decisions. Reflexive mechanisms add to decisionmaking by providing additional options for comparisons (Luhmann 1966: 3). Thinking through more and radically different options is especially important when crossing institutional boundaries and when working with reallife transformations. From a sociological perspective, mechanisms become reflexive if they are applied to themselves, e.g. if planning itself is planned (Luhmann 1966: 2). The capacity for acting in complex real-life situations is therefore enhanced and more space for process innovations given (Lamker 2016).

Role-reflexive planning moves away from focusing on (potential) actions to focusing on the planners themselves - to more effectively plan planning by applying reflexive mechanisms to planning itself (Luhmann 1966: 2). Immediate possible change lies within oneself and one's own processes of thinking, which can be directly altered. The aim is not to reflect about planning actions but about planners acting. It is about reflecting on different ways of thinking before acting, and supporting a process of learning about oneself, one's own tacit knowledge and about alternatives at stake (Helyer 2015: 16 ff.; Lamker 2016: $323 \mathrm{ff}$.). This account also acknowledges two major impossibilities: first, to understand and analyse all uncertainties surrounding the current action situations; second, to find a best way of acting largely by analysing these conditions and by engaging in communication with different actors. The fastest and easiest changes possible are within planners themselves and their role behaviour and associated ways of thinking. Role-reflexive planning can also allow for a greater capacity of self-critique by planners and consideration of the role they enact during their daily work (Fox-Rogers/Murphy 2016: 88). Reflection can be a 'magical window' on new roles and practices: "the confrontation with contingency can be renewed and cultivating reflexivity can help planners to navigate new landscapes of risk and opportunity" (van Assche/Beunen/Duineveld 2017: 224).

Taking game-based ideas into planning discussions is promising as a tool to support new ideas, learning and social or technological innovation (Schrage 1999; cf. Gugerell/Zuidema 2017: $106 \mathrm{ff}$.), as a method for public participation (Poplin 2012), and as a tool for engagement and education (cf. Rumore 2015: $238 \mathrm{ff}$.). Reflection is, at least to a certain extent, an unpredictable process targeted at understanding deeper conflictual references for actions. This can happen in daily practice, but also in playful and game settings. If used in game-based setting, roles foster playful thinking for planners. Play and 
politics can find a meaningful connection that empowers, engages and inspires people beyond instrumental rationality and lobbyism (Hüther/Quarch 2016: 196 ff.). In management, playing has a tradition of use with regard to serious games, innovation and product development (Schrage 1999). Role-based playing can be "a tool for transformative civic education and engagement around science-intensive environmental issues" (Rumore 2015: 3 ), especially because roles are easy to understand and act as a vehicle to bridge boundaries towards other actors (Bisschops/Beunen 2018: $11 \mathrm{ff}$.; Olesen 2018: 315 f.). Playing in relation to transitions offers a dense connection between thinking and acting as well as between innovation, joint learning and education (Gugerell/Zuidema 2017: $106 \mathrm{ff}$.). The art of changing perspectives is connected to the possibility to identify with different roles, to try them out and experiment with them (Hüther/Quarch 2016: 177 ff.; Lamker 2016: 323 ff.; Schulze Dieckhoff/Lamker 2017). Neurobiology and cognition science provide insights here into individual processes of thinking and acting to avoid traps and lockins in thinking (Fürst 2016: 43 ff.). Last, if roles are seen as temporary stabilisations of planning practices, they become a means to improvise in chaotic real-life situations - just like e.g. jazz musicians (Dell 2011: 187 ff.; Barrett 2012; Dell 2017), who "must develop a remarkable degree of empathic competence, and mutual orientation to one another's unfolding" (Barrett 2012: 32). These demands on musicians resemble demands on planners working with spatial transformations. The assumption taken into the following example is that actors can change their own role thinking in playful environments - even beyond the individual game itself. Role-plays therefore become more than closed one-off operations aimed at solving limited specified problems. They enrich past and recent role-based debates in planning research and provide additional ground for developing the future-oriented tools of a more dynamic and reflexive mode of planning.

\section{Experimental pilot workshop: thinking planning as improvising role-play}

\subsection{Improvisation and role-playing towards roles in transition}

Improvisation and planning seem to be opposites, with improvisation excluded from established planning definitions (Wiechmann 2008: 65). However, if dealing with multiple uncertainties at one time and over time, many planners will also need improvisation in their work. Improvisation has to be distinguished from chaos and chance (Dell 2011: $14 \mathrm{f}$.). It is a playful term used in daily practices and in the art of orienting and asserting oneself within a given institutional context (Dell 2014: 128). In organisations, it builds upon known patterns, works with existing institutions and has a shared orientation towards a useful result (Dell 2017: 34). A continuum opens up between planning-only and improvisationonly approaches - with neither of the two poles working effectively without the other (Dell 2017: $42 \mathrm{f}$.). If we do not have complete knowledge - which is usually the case in planning - there remains the momentum of improvisation at least towards the implementation of ideas. This implies more of a different and open planning approach than a description of non-planning (cf. Lamker 2016: 325 ff.). Improvisation is either made visible or remains subtle within professional and social networks and allows for fast reactions to formerly unknown changes (cf. Emirbayer/Mische 1998: 1000). On the other hand, transformative changes triggered by civil society actors involve large amounts of improvisation, not least in open settings like living labs. How to improvise is the result of learning and reflecting in practice (Schön 1983). However, research only randomly focuses on planned aspects of seemingly chaotic and improvisational organisations and, ultimately, cities (Dell 2011).

Hence, any role description needs to leave space for discretion in specific situations, remain open for unexpected and unknown events and allow adjustments to the individual characteristics of planners. Improvisation in this sense is strongly connected to agency for change, or more broadly the "exercise of situationally based judgment [that] has been variously termed practical wisdom, prudence, art, tact, discretion, application, improvisation, and intelligence" (Emirbayer/ Mische 1998: 994). Roles provide preliminary and imperfect potentialities that allow for time- and contextsensitive improvisation by actors in real-life situations (cf. Dell 2011: 142 ff.). In this light, improvisation does not equate to a planning approach, but improvising is an essential part of any planning activity - independent of whether it is being done by professional planners or civil society. Improvisation provides common ground between planners and other actors. Who acts becomes part of what is acted upon (Dell 2011: 146), thereby focusing on joint reflection in action and self-reflexivity to gain abstract means of comparison (Luhmann 1966: 3; Luhmann 1983: 47 f.). 


\subsection{Background: experimental pilot workshop}

Role-based thinking in planning for transitions functioned as the groundwork upon which to conduct an experimental role-play. This was developed as a single pilot project to refine conceptual ideas on role-reflexive planning and to confront the basic thoughts outlined in Sections 2 and 3 with the realities of different people: 25 people came together in Wuppertal in September 2017 to think about 'processes of post-growth planning' (original German title: Prozesse einer Postwachstumsplanung). The session was part of a workshop series of the Young Professionals' Forum in North Rhine Westphalia within the German Academy for Spatial Research and Planning (ARL). The predominant background of these 25 people was research/university (nine people), civil society activism (five people), local neighbourhood (four people), professional planners (two people) and unknown backgrounds (four people). The age of participants ranged from around 20 to 60 years, and three hours were available. The workshop took place in Wuppertal at Utopiastadt e.V., a local civil society initiative, on 21 September 2017. Utopiastadt uses the building and surroundings of the abandoned Mirke railway station. It lies adjacent to the newly established cycle trail Nordbahntrasse and presents itself as a creative cluster and initial part of an ongoing exchange between culture and society as part of the local neighbourhood, its engagement and its utopias. The old waiting room for third-class passengers provided an easily accessible space for thinking. It was open to the outside, unfinished and with colourful decoration. The room was equipped with tables and chairs in groups but these were not arranged in a hierarchy or in such a way that people or objects confronted one another. Food services were available outside from Utopiastadt and participants had the opportunity to walk out to eat and enjoy the sunset, and then come back to put down their ideas.

The workshop was part of a critical discussion of established planning thoughts and the unquestioned truths of planners. It thereby targeted an intended transition of planning towards post-growth planning (see also Schulze Dieckhoff/Lamker 2017). The core of this critical debate is to foster reflexivity within planning. It challenges unquestioned faith in the positive effects of growth and the perceived impossibility to see any importance in planning when its orientation towards spatial, demographic or economic growth is loosened. This growth-orientation hinders the transition of planning and the assigned roles of planners. It hampers joint thinking about the uses of limited space across actors who see growth as the most important goal (e.g. many private equity funds) and those who do not see any importance in growth at all (e.g. many local civil society initiatives). The experiment connected planning, roles and improvisation in real-life situations. It started with transition roles identified from theory and initial discussions and intended to work towards a broader understanding about roles in transition and implications for a different way of understanding and ultimately doing planning (Lamker 2016: 320 ff.; cf. Wittmayer/Avelino/van Steenbergen et al. 2017). It posed the questions: When thinking in roles, what can we learn about our behavioural patterns and ourselves? How do we play with possible roles and time? Which elements are necessary and how do we combine them? How do we build up a planning process leading to a decision?

\subsection{Transition roles for spatial transformations}

The first step is to identify transition roles that are relevant for working with large-scale spatial transformations. Rolebased reflection implies a number of different and distinct roles that cover a variety of expected possible patterns (Lamker 2016: 116 ff.). First, it is likely that transition roles emphasise more recent research developments and are less evident in traditional technical and administrative planning. If there is the often-discussed dichotomy between public planning and transformative practice by citizens and civil society, this should not be re-enforced in this setting but rather bridges for mutual understanding should be made possible. One foundational concept of transition is interpretation and the way in which we use cognitive rules, how we make sense of the world and our social interactions, and how we are able to construct different meanings together (Geels/Schot 2007: 414 f.). Transition can search for possible changes within existing rules, for ways of adjusting the rules and developing more effective options for navigating change in existing institutions (Bisschops/Beunen 2018: 13 f.). Gradual change incorporates the creation of new rules (layering) as well as the reinterpretation of existing ones (conversion). (Bisschops/Beunen 2018: 11). Second, roles used for experimental play need to be limited in number, easy to understand for different people and must vary significantly from one another. They have to provide ground for reflection in action and, beyond that, for experimentation, improvisation and play (de Leo/ Forester 2017: 203). Only then can roles become vehicles 
for comparison and motivation in established procedures (cf. Luhmann 1983: 47 f.). Third, any such endeavour has to be open for new roles emerging during the process. A dynamic and transforming society influences the roles and positions of planners continuously and has to be open to the unfolding of different and new roles (de Roo 2018: 2; Wittmayer/Avelino/van Steenbergen et al. 2017: $53)$.

The background for thinking was a brownfield site next to the workshop room ('Utopiastadt Campus') in a dense setting in northern Wuppertal between a late-nineteenth-century urban neighbourhood, a well-established cycleway on old railway tracks (Nordbahntrasse) and a motorway. The goal was to develop a process and to think through this opportunity in only one role, and to come up with initial ideas on what this process could look like and how a decision might be made later. Eight questions and their respective answers led to a story-like description covering a picture of each role that workshop participants were able to grasp within a short time (Schulze Dieckhoff/Lamker 2017). Each role gave meaningful answers to the following questions (cf. Lamker 2016: 120 ff.):

- Which behavioural patterns are characteristic?

- How do you deal with different pieces of information?

- How do you deal with diverse actors?

- Which questions do you pose?

- What do you question?

- What is the core of your actions?

- For which actions do you take responsibility?

- What does success mean for you?

The role-play used four roles that are elaborated in Lamker (2016: 122 ff.): Technical Problem-Solver, Moderator, Strategic Navigator and Explorer. They were supplemented by four additional roles (see Table 1). Three of them (Advocator/Protector, Broker and Leader) lie along the interface between political science, management theory and communicative planning theory (cf. Lamker 2016: 114). The Inspirer served as another role focusing on motivational aspects towards other actors, acknowledging the importance of engaging and empowering within planning-related transition research. A Joker role made it possible to create one's own pattern based on core elements and the above-mentioned questions. Each role had four to six possible behavioural patterns to structure the courses of action that were thinkable. Two were indicated as most important (printed in bold in Table 1). Possibilities were: administering, analysing, arguing, arranging, coordinating, criticising, determining, developing, discussing, evaluating, experimenting, exploring, managing, moderating, navigating, observing, persuading, questioning, securing, supporting, testing (adapted from Lamker 2016: 222 f., translated). Role descriptions did not include information about institutional positions, hierarchical status, substantial targets or statistical and economic facts about the spatial situations or existing thoughts by others.

Overall, nine roles were elaborated in the same way (see Table 1). The workshop group separated into groups of five to seven persons. Each of the four groups were given two role cards from which to choose one for playing. These one-page cards included an overall statement of the background and questions (playing environment) as well as a short storyline of each role and possible behaviours (playing rules). The playing environment included the reminder, "It's a game! Think freely about what you would do in your role. There are no further limitations" (own translation). In addition, each card was given a short headline (storyline) and one inspiring quote by a relevant researcher or theorist. For example, the Inspirer role used "Thinking positive futures and inspiring towards active transformation" and a quote by the German neurobiologist Gerald Hüther about the importance of inviting, encouraging and inspiring people to have positive or better experiences (Hüther 2004).

The emphasis lay on joint learning and engaging without starting with established differences in knowledge, and therefore power. All participants were provided with flipchart paper, pencils, paper, colours and further material for drawing, cutting and creating. The three-hour workshop followed an eight-step structure:

a. Welcome and introduction

b. Input: planning and improvisation (Dr. Gérard Hutter)

c. Role-play (including summarising questions)

d. Joint summary and discussion

e. Open space break

f. Inputs: processes of urban planning (Dr. Christian Lamker) and Utopiastadt Campus (Matthias Wanner)

g. Joint discussion

h. Conclusion

The short introductory part (10 minutes) included a welcome by Utopiastadt e.V. and short background information on developments around the term 'postgrowth planning' (German: Postwachstumsplanung) as preliminarily defined around a collective of young researchers and practitioners in Germany. The following input (Part b, 15 minutes) was meant to induce a creative atmosphere by opening a perspective on planning inspired by examples from music, ranging from 
Table 1: Planning roles

\begin{tabular}{|c|c|c|}
\hline Role & Storyline & Behavioural patterns \\
\hline Advocator/Protector & $\begin{array}{l}\text { Protecting and creating opportunities in life for all } \\
\text { against powerful interests }\end{array}$ & $\begin{array}{l}\text { arranging, criticising, discussing, persuading, questio- } \\
\text { ning, supporting }\end{array}$ \\
\hline Broker & $\begin{array}{l}\text { Brokering future prospects by constructing and } \\
\text { arranging property relations }\end{array}$ & analysing, arranging, arguing, managing, persuading \\
\hline Explorer & $\begin{array}{l}\text { Testing boundaries and exploring future potentia- } \\
\text { lities }\end{array}$ & experimenting, exploring, observing, testing \\
\hline Inspirer & $\begin{array}{l}\text { Thinking positive futures and inspiring active } \\
\text { transformation }\end{array}$ & analysing, developing, questioning, managing \\
\hline Leader & $\begin{array}{l}\text { Leading towards a better future and persuading to } \\
\text { act }\end{array}$ & arguing, coordinating, leading, persuading \\
\hline Moderator & $\begin{array}{l}\text { Designing the future as a collective moderated } \\
\text { process }\end{array}$ & discussing, moderating, supporting \\
\hline Strategic Navigator & $\begin{array}{l}\text { Strategic navigating and coordinating towards an } \\
\text { integrated spatial future }\end{array}$ & $\begin{array}{l}\text { arguing, coordinating, managing, navigating, persua- } \\
\text { ding }\end{array}$ \\
\hline $\begin{array}{l}\text { Technical Problem- } \\
\text { Solver }\end{array}$ & Problem-solving for the best future & $\begin{array}{l}\text { arranging, analysing, determining, evaluating, questi- } \\
\text { oning }\end{array}$ \\
\hline Joker & None & $\begin{array}{l}\text { administering, analysing, arguing, arranging, coordina- } \\
\text { ting, criticising, determining, developing, discussing, eva- } \\
\text { luating, experimenting, exploring, managing, moderating, } \\
\text { navigating, observing, persuading, questioning, securing, } \\
\text { supporting, testing }\end{array}$ \\
\hline
\end{tabular}

prescribed classical music to improvised jazz. The most important part was the following role-play (60 minutes). Participants were randomly mixed and none of the role descriptions matched their actual role in work, study or life. One group each used the roles Advocate/Protector, Inspirer, Strategic Navigator and Leader. Everyone had the task of thinking about the proposed procedural steps with their interdependencies, necessary external input and information, cooperation with different actors and exit points, which lead to dead ends within the given role. Groups were later asked to write down the most important topic in their discussion and the largest problem that they could not solve together without abandoning the rules of the game, i.e. their assigned role descriptions. This led to a joint summary and discussion (Part d, 20 minutes) followed by an open space break for dinner, drinks and open discussions across tables (Part e, 20 minutes). Following this, the organisers provided background on established ways to conceptualise planning processes and on the example of 'Utopiastadt Campus' (Part f, 20 minutes). A second discussion followed (20 minutes). It focused on defining factors of success for planners and the amount of control, openness and legitimacy for planning (and planners). The last part invited participation in an ongoing discussion about which role or roles should be favoured by 'post-growth planners' (Part h, 15 minutes).

\subsection{Insights for using role-reflexive methods}

The role-play part of the workshop and the following summary and discussion parts provided important insights. First, roles made it possible to think differently to one's own position and expected behavioural patterns. Role-based thinking is divorced from a static coupling with formal positions or prejudgments about possible behavioural patterns (cf. Lamker 2016: 93 ff.). Helpful in this regard is a different physical space that erodes differences, establishes standing out and stepping back and in itself includes an improvisational element. The open environment in Utopiastadt did not allow the establishment of barriers between groups of actors upfront. When participants were introduced, the information given was deliberately limited and no stark differences in position or experience was emphasised. The spatial setup itself was organised so as to open up space for workshop participants to engage in discussions with their given role and make it part of their own thinking. 
If successful planning has to address its institutional context (Lissandrello/Grin 2011: 226), this allows for creative discretion in this regard. The starting point is to leave existing barriers beyond consideration and then, in a later step, to take them back to what is possible within the real-life environments of the respective actors. The roles focused on different topics that emerged as part of their thinking. Neighbourhood-based social integration and mix of uses (Advocator/Protector), questions of who has needs, who is allowed to fulfil them and who takes decisions (Inspirer), goals, visions and coordination (Strategic Navigator) and a way to work along the lines of: plan, do, check, act (Leader). These topics are all part of planning definitions, but stress very different aspects that are only uncovered by having considered multiple roles of planners, i.e. the multiple self-descriptions and multiple meanings available (Luhmann 1987: 637; Kaplan/Orlikowski 2013: 990). Simultaneously, different problems of the respective roles surfaced: addressing the disadvantaged, funding and organisation (Advocator/ Protector), linear versus chaotic procedures (Inspirer), the best processes of developing goals (Strategic Navigator) as well as time and leadership style (Leader). The workshop setup and provided roles were taken from critical approaches of post-growth planning. However, role-reflexive methods increase options for comparison and improvisation. As a stand-alone tool, they do not produce better, or more just, results.

Second, roles bridge across different backgrounds, knowledge and prior experiences. The workshop and way of thought triggered dialogue between people who would usually only talk in unequal settings (e.g. expert speaker and audience; experienced planning professor and local laypeople). As the session was about developing a process, no one had an advantage in terms of knowing facts others could not evaluate during a workshop setting. It was important in this setting to prevent anything like a 'war of facts' and focus on the 'play with ideas', as a much more engaging and emotional approach for involving diverse actors in a shared process (cf. Hüther/ Quarch 2016: 199). If our "social problems are emotional issues argued under emotionally charged conditions" (Weick 1984: 48), playing with roles offers potentials to acknowledge an emotional dimension within open and co-creative settings. Emotions are an integral part of any playful approach and the rules of the game should evoke them and allow them to unfold (cf. Kampelmann/ Kaethler/Hill 2018). However, working with improvisation and play does not need a deep prior understanding of individual emotional processes.
Third, assumed roles get increasingly difficult to change. Participants needed some time to enter 'their' role's way of thinking, but they established their own interpretation and made it part of their own thinking. Even if the role was contrary to their usual behaviour, many participants started to believe in their role and tried to argue for it. The space of thinking created during the role-play also became emotional. Participants insisted on their role even after the discussion was opened up to different ideas. Local activists continued to think as market-oriented Leaders, researchers developed a strong argument for disadvantaged groups as Advocators, and Inspirers developed ideas about how to extend the scope to include further actors. Partly in contrast to this observation: the more facts given, the less creative role thinking was possible. After initial open role-playing, participants were given additional facts on the brownfield site, the actors involved, and the ideas and implementation problems (Part $f$ of the workshop). For many, this triggered a switch back to discussing simple dichotomies between prescribed roles for planners, for developers, for civil society and alike. It proved helpful to take two steps forward during the game and, in a second phase, to think a step back to what is actually possible by each of those involved. This may be an important trigger: first to overcome cognitive barriers and then have two perspectives from both sides of these barriers (cf. Fürst 2016: $45 \mathrm{ff}$.). A momentum of change in role behaviour lasts longer than the game situation itself. This should not be downplayed because changing oneself and one's self-images - i.e. being oneself in transition - is one of the most challenging and encompassing options. It is rather a reminder that having more information available is not always beneficial to finding creative solutions. Existing research on role-plays has proven this for building a space-based consensus (Innes/Booher 1999) or for deciding about future land-uses and shifting decisionmaking from the public administration to a diversity of actors (Scholles 2008). Role-reflexive planning ideas might lead to a diversified toolbox for developing process layouts in fluid transformational environments. Issues of implementation slowed down the creative discussion as attention turned to looking for the potentials of planning processes to support the developed courses of action. Role-playing at least allows any planner to engage in thinking in different ways without giving up their position. The largest challenge is to keep creative forces alive beyond a single pilot experiment and to move on further to actual spatial changes - and ultimately larger scale transformations. 


\section{Concluding remarks: planning transitions for spatial transformations}

On the immediate level and for educational or experimental purposes, playful settings hold the potential to challenge and change the role thinking of the actors involved. Working on role-reflexive planning takes participants to the heart of a different way of experimenting with planning thoughts and processes. Insights from using a role-based approach to improvise, to play and to rethink planning have shown the potential of this approach as a cornerstone of a different way of understanding and conceptualising planning. Rolereflexive planning can be especially important when the intention is to open boundaries between professional planners and civil society actors and to achieve gradual change over time, perceiving transition as change caused by small transformative actions within existing institutions (Bisschops/Beunen 2018: 14). Current practices benefit from having this additional tool available. However, there are limitations. Reflective processes can never be straightforward, completely intentional or without unknown side-effects (Schön/Rein 1994: 37 ff.). Systems theory sees the importance of reflection on the abstract level to gain comparisons (Luhmann 1966: 3). A structured procedure can, due to its own complexity, produce critique and alternatives within its own system (Luhmann 1983: 50). Dynamic, interrelated and critical alternatives are important for challenging established thoughts like the growth-orientation of planning. The setting taken in this paper makes it easy to be critical and creative, but less easy to take the step towards proactive action and actual change. Role-reflexive planning needs further elaboration towards definitions of success and failure as well as the data and information that are needed for different roles. Adequate instruments and methods need to support role-reflexive processes as such.

Seen from a broader perspective on planning in transition, playful and game-like settings provide hope for change across established thoughts. This may bridge existing but as yet unintegrated approaches to fostering urban transformations and related roles from art (Holub/ Hohenbüchler 2014; Aßmann/Bader/Shipwright et al. 2017), cultural science (Reinermann/Behr 2017), governance and institutional change (Loorbach/ Wittmayer/Shiroyama 2016; Bisschops/Beunen 2018) and planning (Lamker 2016; Loepfe/Eisinger 2017; de Roo 2018; Knieling/Klindworth 2018). Planning research would benefit from extending role-based thinking to include more elements of reflexivity and openness towards emerging roles and flexible uses thereof. Moreover, the opening up of creative, experimental and improvising spaces of dialogue fosters thinking beyond mental and institutional boundaries on shared actions. In turn, this emphasis integrates joint efforts back into existing institutions, rules and instruments to achieve gradual change in a desired direction (Bisschops/ Beunen 2018: $11 \mathrm{ff}$.). Role-based thinking triggers creative forces of motivation and thereby supports actors in a joint setting to feel united with others, at least to a certain extent. If developed further, planners might also be conceptualised as role-players. Research on playful settings is promising to help find common ground on shared roles, behavioural patterns and their endurance beyond individual situations.

This paper has called for the development of rolereflexive thinking and playing as an important supplement to immediate and future planning practice and research. It has piloted how roles can be used within experimental and playful settings to learn and reflect about different behavioural patterns across highly diverse sets of actors from various institutional backgrounds. Enabling reflexive engagement depends upon the creation of an environment that fosters the crossing of mental barriers instead of re-enforcing them. Spatial transformations in which planners are meaningful actors require roles as a joint approach of creative thinking beyond traditional boundaries between planners and non-planners or between experts and laypeople. Transformation involves the whole of society and has the potential to yield large system changes. Accordingly, planning in transition should also broaden its scope and its available and enacted roles. Roles, reflexivity and playful approaches can become meaningful spaces of hope for planners themselves and for their perception in society.

Acknowledgement: The author expresses special thanks for continuous support with conceptualising and organising the workshop on processes of post-growth planning to Gérard Hutter, Nadine Mägdefrau and Viola Schulze Dieckhoff as well as to the local team at Utopiastadt e.V. in Wuppertal. Furthermore, thanks to Meike Levin-Keitel for valuable comments on an earlier draft of this article and to the German Academy for Spatial Research and Planning (ARL) for paying the costs for a workshop room. We acknowledge financial support by Deutsche Forschungsgemeinschaft and Technische Universität Dortmund/TU Dortmund University within the funding programme Open Access Publishing. 


\section{References}

Abbott, J. (2005): Understanding and Managing the Unknown: The Nature of Uncertainty in Planning. In: Journal of Planning Education and Research 24, 3, 237-251. doi: 10.1177/0739456X04267710

Aßmann, K.; Bader, M.; Shipwright, F.; Talevi, R. (Hrsg.) (2017): Explorations in Urban Practice. Barcelona.

Barnett, C.; Parnell, S. (2016): Ideas, implementation and indicators. Epistemologies of the post-2015 urban agenda. In: Environment and Urbanization 28, 1, 87-98. doi: 10.1177/0956247815621473

Barrett, F.J. (2012): Yes to the Mess: Surprising Leadership Lessons from Jazz. Boston.

Bisschops, S.; Beunen, R. (2018): A new role for citizens' initiatives. The difficulties in co-creating institutional change in urban planning. In: Journal of Environmental Planning and Management. doi: 10.1080/09640568.2018.1436532

Bulkeley, H.; Coenen, L.; Frantzeskaki, N.; Hartmann, C.; Kronsell, A.; Mai, L.; Marvin, S.; McCormick, K.; van Steenbergen, F.; Voytenko Palgan, Y. (2016): Urban living labs: governing urban sustainability transitions. In: Current Opinion in Environmental Sustainability 22, 13-17. doi: 10.1016/j.cosust.2017.02.003

Christensen, K.S. (1985): Coping with Uncertainty in Planning. In: Journal of the American Planning Association 51, 1, 63-73. doi: 10.1080/01944368508976801

de Leo, D.; Forester, J. (2017): Reimagining planning. Moving from reflective practice to deliberative practice - a first exploration in the Italian context. In: Planning Theory and Practice 18, 2, 202-216. doi: 10.1080/14649357.2017.1284254

de Roo, G. (2018): Ordering Principles in a Dynamic World of Change - On social complexity, transformation and the conditions for balancing purposeful interventions and spontaneous change. In: Progress in Planning 125, 1-32. doi: 10.1016/j.progress.2017.04.002

Dell, C. (2011): ReplayCity. Improvisation als urbane Praxis. Berlin.

Dell, C. (2014): Die improvisierende Organisation. Bielefeld.

Dell, C. (2017): Organisation musikalisch denken. In: Stark, W.; Vossebrecher, D.; Dell, C.; Schmidhuber, H. (Hrsg.): Improvisation und Organisation. Muster zur Innovation sozialer Systeme. Bielefeld, 31-46.

Egermann, M.; Hutter, G. (2014): Perspektiven für die Annäherung der Raum- und Transitionforschung - am Beispiel des EU-Projekts ARTS. In: PND|online 3, 1-9.

Emirbayer, M.; Mische, A. (1998): What Is Agency? In: American Journal of Sociology 103, 4, 962-1023. doi: 10.1086/231294

Fox-Rogers, L.; Murphy, E. (2016): Self-perceptions of the role of the planner. In: Environment and Planning B 43, 1, 74-92. doi: $10.1177 / 0265813515603860$

Friend, R.M.; Anwar, N.H.; Dixit, A.; Hutanuwatr, K.; Jayaraman, T.; McGregor, J.A.; Menon, M.R.; Moench, M.; Pelling, M.; Roberts, D. (2016): Re-imagining Inclusive Urban Futures for Transformation. In: Current Opinion in Environmental Sustainability 20, 67-72. doi: 10.1016/j.cosust.2016.06.001

Fürst, D. (2016): Denkfallen bei planerischen Abwägungsund Bewertungsverfahren - Erkenntnisse aus den Kognitionswissenschaften. In: Othengrafen, F.; SchmidtLauber, B.; Hannemann, C.; Pohlan, J.; Roost, F. (Hrsg.): Jahrbuch StadtRegion 2015/2016. Schwerpunkt: Planbarkeiten. Opladen, 43-59.
Geels, F.W.; Schot, J. (2007): Typology of sociotechnical transition pathways. In: Research Policy 36, 3, 399-417. doi: 10.1016/j. respol.2007.01.003

Gugerell, K.; Zuidema, C. (2017): Gaming for the energy transition. Experimenting and learning in co-designing a serious game prototype. In: Journal of Cleaner Production 169, 105-116. doi: 10.1016/j.jclepro.2017.04.142

Healey, P.; Underwood, J. (1978): Professional ideals and planning practice. A report on research into planners' ideas in practice in London Borough planning departments. In: Progress in Planning 9, 2, 73-127. doi: 10.1016/0305-9006(78)90005-3

Helyer, R. (2015): Learning through reflection. The critical role of reflection in work-based learning (WBL). In: Journal of WorkApplied Management 7, 1, 15-27. doi: 10.1108/JWAM-10-2015003

Hillier, J. (2010): Strategic Navigation in an Ocean of Theoretical and Practice Complexity. In: Hillier, J.; Healey, P. (Hrsg.): The Ashgate research companion to planning theory. Conceptual challenges for spatial planning. Farnham, 447-480.

Hölscher, K.; Wittmayer, J.M.; Loorbach, D. (2018): Transition versus transformation: What's the difference? In: Environmental Innovation and Societal Transitions 27, 1-3. doi: 10.1016/j. eist.2017.10.007

Holub, B.; Hohenbüchler, C. (Hrsg.) (2014): Planning Unplanned. Darf Kunst eine Funktion haben? Towards a new function of art in society. Nürnberg.

Howe, J.; Langdon, C. (2002): Towards a Reflexive Planning Theory. In: Planning Theory 1, 3, 209-225. doi: 10.1177/147309520200100302

Hüther, G. (2004): Die Macht der inneren Bilder. Wie Visionen das Gehirn, den Menschen und die Welt verändern. Göttingen.

Hüther, G.; Quarch, C. (2016): Rettet das Spiel! Weil Leben mehr als Funktionieren ist. München.

Ibert, O. (2009): Von „der“ Planung zu multiplen Planungen. Strategische Entscheidungen unter Bedingungen hoher Komplexität und geringer Umweltkontrolle. In: Geographica Helvetica 64, 2, 89-97. doi: 10.5194/gh-64-89-2009

Innes, J.E.; Booher, D.E. (1999): Consensus Building as Role Playing and Bricolage. Toward a Theory of Collaborative Planning. In: Journal of the American Planning Association 65, 1, 9-26. doi: 10.1080/01944369908976031

Kampelmann, S.; Kaethler, M.; Hill, A.V. (2018): Curating complexity: An artful approach for real-world system transitions. In: Environmental Innovation and Societal Transitions 27, 59-71. doi: 10.1016/j.eist.2017.10.005

Kaplan, S.; Orlikowski, W.J. (2013): Temporal Work in Strategy Making. In: Organization Science 24, 4, 965-995. doi: 10.1287/ orsc. 1120.0792

Knieling, J.; Klindworth, K. (2018): The Self-Conception of German Planners as Pioneers for Sustainability Transition. In: TasanKok, T.; Oranje, M. (Hrsg.): From Student to Urban Planner. Young Practitioners' Reflections on Contemporary Ethical Challenges. New York, 198-214.

Lamker, C.W. (2016): Unsicherheit und Komplexität in Planungsprozessen. Planungstheoretische Perspektiven auf Regionalplanung und Klimaanpassung. Lemgo. = Planungswissenschaftliche Studien zu Raumordnung und Regionalentwicklung 6.

Levin-Keitel, M.; Mölders, T.; Othengrafen, F.; Ibendorf, J. (2018): Sustainability Transitions and the Spatial Interface: Developing 
Conceptual Perspectives. In: Sustainability 10, 6, 1-15. doi: 10.3390/su10061880

Lissandrello, E.; Grin, J. (2011): Reflexive Planning as Design and Work. Lessons from the Port of Amsterdam. In: Planning Theory and Practice 12, 2, 223-248. doi: 10.1080/14649357.2011.580156

Loepfe, M.; Eisinger, A. (2017): Assemblages for Urban Transformation. In: disP - The Planning Review 53, 1, 20-31. doi: 10.1080/02513625.2017.1316526

Loorbach, D.; Wittmayer, J.M.; Shiroyama, H.; Fujino, J.; Mizuguchi, S. (Hrsg.) (2016): Governance of Urban Sustainability Transitions. European and Asian Experiences. Tokyo. doi: 10.1007/978-4-431-55426-4

Luhmann, N. (1966): Reflexive Mechanismen. In: Soziale Welt 17, 1, 1-23.

Luhmann, N. (1983): Legitimation durch Verfahren. Frankfurt am Main.

Luhmann, N. (1987): Soziale Systeme. Grundriß einer allgemeinen Theorie. Frankfurt am Main.

Luhmann, N. (1997): Die Gesellschaft der Gesellschaft. Band 1. Frankfurt am Main.

Olesen, K. (2018): Teaching planning theory as planner roles in urban planning education. In: Higher Education Pedagogies 3 , 1, 302-318. doi: 10.1080/23752696.2018.1425098

Poplin, A. (2012): Playful public participation in urban planning: A case study for online serious games. In: Computers, Environment and Urban Systems 36, 3, 195-206. doi: 10.1016/j. compenvurbsys.2011.10.003

Rabinovitz, F.F. (1969): City politics and planning. New York.

Rauws, W. (2017): Embracing Uncertainty Without Abandoning Planning. Exploring an Adaptive Planning Approach for Guiding Urban Transformations. In: disP - The Planning Review 53, 1, 32-45. doi: 10.1080/02513625.2017.1316539

Reinermann, J.-L.; Behr, F. (Hrsg.) (2017): Die Experimentalstadt. Kreativität und die kulturelle Dimension der Nachhaltigen Entwicklung. Wiesbaden. doi: 10.1007/978-3-658-14981-9

Rittel, H.W.J. (1972): On the Planning Crisis. Systems Analysis of the 'First and Second Generations'. In: Bedriftsøkonomen 8, 390-396.

Rumore, D.L. (2015): Role-play simulations: a tool for transformative civic education and engagement around science-intensive environmental issues. PhD Thesis, Massachusetts Institute of Technology.

Scholl, C.; Kemp, R. (2016): City Labs as Vehicles for Innovation in Urban Planning Processes. In: Urban Planning 1, 4, 89-102. doi: 10.17645/up.v1i4.749

Scholles, F. (2008): Planspiel. In: Fürst, D.; Scholles, F. (Hrsg.): Handbuch Theorien und Methoden der Raum- und Umweltplanung. Dortmund, 393-402.

Schön, D.A. (1983): The reflective practitioner. How professionals think in action. New York.

Schön, D.A.; Rein, M. (1994): Frame reflection. Toward the resolution of intractable policy controversies. New York.

Schrage, M. (1999): Serious play. How the world's best companies simulate to innovate. Boston.

Schulze Dieckhoff, V.; Lamker, C. (2017): Prozesse einer Postwachstumsplanung. https://www.postwachstum.de/ prozesse-einer-postwachstumsplanung-20171026 (11.12.2018).

Steele, W. (2009): Australian Urban Planners. Hybrid Roles and Professional Dilemmas? In: Urban Policy and Research 27, 2, 189-203. doi: 10.1080/08111140902908873 van Assche, K.; Beunen, R.; Duineveld, M. (2017): Witchcraft, oracle, and magic in the kingdom of planning. A reflection on planning theory and practice inspired by Ernest Alexander. In: Planning Theory 16, 2, 223-226. doi: 10.1177/1473095216676747

WBGU - Wissenschaftlicher Beirat der Bundesregierung Globale Umweltveränderungen (2016): Der Umzug der Menschheit: Die transformative Kraft der Städte. Hauptgutachten. Berlin.

Weick, K.E. (1984): Small wins. Redefining the scale of social problems. In: American Psychologist 39, 1, 40-49. doi: 10.1037/0003-066X.39.1.40

Wiechmann, T. (2008): Planung und Adaption. Strategieentwicklung in Regionen, Organisationen und Netzwerken. Dortmund.

Wiechmann, T.; Hutter, G. (2008): Die Planung des Unplanbaren. Was kann die Raumplanung von der Strategieforschung lernen? In: Hamedinger, A.; Frey, O.; Dangschat, J.S.; Breitfuss, A. (Hrsg.): Strategieorientierte Planung im kooperativen Staat. Wiesbaden, 102-121. doi: 10.1007/978-3-531-90804-5

Wittmayer, J.M.; Avelino, F.; van Steenbergen, F.; Loorbach, D. (2017): Actor roles in transition. Insights from sociological perspectives. In: Environmental Innovation and Societal Transitions 24, 45-56. doi: 10.1016/j.eist.2016.10.003

Wittmayer, J.M.; Hölscher, K. (2016): Transformation Research Goals, Contents, Methods. Expert workshop, June 14, 2016, in Berlin. Rotterdam. 